\title{
Livestock trade and devolution in the Somali-Kenya transboundary corridor
}

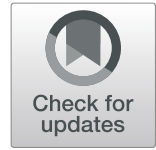

Philemon Ong'ao Ng'asike $^{1 *}$ (D) Finn Stepputat ${ }^{2}$ and Jesse Theuri Njoka ${ }^{1}$

\begin{abstract}
After the collapse of the central Somali state in 1991, Somali livestock trade has increasingly been re-oriented towards terminal markets in central and coastal Kenya, helped by the more recent trade liberalization in Kenya. The predominantly informal cross-border trade (ICBT) has nurtured local livelihoods and government revenues in Kenya, where informal transactions and formal regulation overlap in the Somali-fed livestock supply chains. This article analyses the practices and dynamics that characterize Somali-Kenyan cross-border livestock trade, and proceeds to point out important policy issues that have emerged after the devolution of key state functions and regulation to county governments. The article finally highlights areas of collaboration between the national and county governments that are necessary to achieve a credible supply of meat in Kenyan and international markets. By doing so, it explores the linkage between changes in the political economy of cross-border livestock trade, and the unintended impact of decentralization on the governance of livestock supply chains.
\end{abstract}

Keywords: Livestock markets, Cross-border trade, Trade liberalization, Supply chain, Decentralization

\section{Introduction}

When the central Somali state collapsed in 21st January 1991 and continued violence blocked the usual marketing routes for livestock in the southern parts of Somalia (Kismayo and Mogadishu), Somali livestock traders increasingly took their business across the border to Kenya (Luling 1997; Ahmed and Green 1999; Little 2005; Mahmoud 2010; Little et al. 2015). Since then, livestock from Somalia has turned Garissa's livestock market into one of the largest in the region, and Somali traders have helped alleviate the meat deficit that characterizes domestic Kenyan markets; they have furthermore nurtured Kenyan exports of meat and livestock. ${ }^{1}$ However, due to

\footnotetext{
${ }^{1}$ In 2010, Kenyan meat export to Qatar and UAE alone was valued at US\$32 million (Kshs. 3.2 billion) (USAID 2012), and figures have been going up. In 2013, IGAD estimated that the contribution of livestock to Somalia's economy was US $\$ 8.157$ billion (Kshs. 0.8157 trillion), with approximately 192 million USD being derived from exports of live animals (Too et al. 2015).
}

\footnotetext{
* Correspondence: ongasike@gmail.com

${ }^{1}$ Department of Land Resource Management and Agricultural Technology, University of Nairobi, Nairobi, Kenya

Full list of author information is available at the end of the article
}

the long and porous border between Somalia and Kenya, as well as the generally limited or security-focused presence of state institutions in marginalized north-east Kenya, many aspects of livestock trade continue to be 'informal'. Somali livestock never figures as being imported, and the animals move in and out of formal controls and certifications on their way to terminal markets and abattoirs in central and coastal Kenya.

This article explores the intersection between dynamics of livestock trade in the Somali-Kenya corridor and the governmental regulation and support of livestock trade after devolution, the ambitious decentralization of powers and functions from the central to county governments that Kenya embarked on in 2013. This is also where our study adds to former studies of livestock trade in the Garissa corridor (Little 2003, 2005; Mahmoud 2008, 2010; Little et al. 2015). In the first half of the article, we present an analysis of the in/formal practices, authorities and logics that characterize this livestock trade. We begin in Garissa, which is a major hub for livestock trade in the region, before looking upstream towards the sourcing in the Somali-Kenyan borderlands and downstream to the terminal markets and abattoirs 
in Nairobi. Overall, traders want to see livestock move as speedily and smoothly as possible towards the end markets since delays, disruptions and the duress of prolonged transport represent increased expenses for fodder, water and protection, as well as significant risks in terms of livestock health and weight loss.

In the second half of the article, we point out important policy fields and issues that devolution and current forms of livestock trade bring into play. These issues relate to informal cross-border trade (ICBT), which is a central government issue; to the management of livestock market places which has been delegated to county governments; and to policy fields that lie between county and national government responsibilities, such as road infrastructure, abattoirs and drought responses.

The article argues that devolution has improved access to public services such as certification, licencing and veterinary assistance and that, as a result, informality is gradually fading in the borderlands of Kenya and Somalia. However, devolution has also increased taxation, created barriers for livestock trade and increased the risk that oligopolies around county executives are reinforced. The limited human and financial resources of county administrations challenge their active role in livestock market development, and some of the most urgent issues for supporting a more productive livestock trade-such as disease control, roads and disaster responses-are located at the intersection of county and national government policy areas and need close cooperation between counties and the national government. This points towards the importance of fora like the Kenya Livestock Marketing Council (KLMC) that presently coordinates livestock matters at the county level.

\section{Study area and methodology}

The data for this study were produced through fieldwork at Garissa and Nairobi livestock markets and abattoirs. Garissa municipality hosts the biggest livestock market in East and Central Africa (Ng'asike 2019). The cosmopolitan nature and the demographical changes are linked to being the central headquarters of the former NorthEastern Province and later a destination of entrepreneurs (Weitzberg 2015) arriving from Somalia after the state collapse of 21st January 1991 (Fig. 1).

Qualitative data collection took place from January to July 2018, and an additional survey based on structured questionnaires was carried out between November 2018 and February 2019. Both formal (focus group) and informal discussions were held with livestock trekkers, traders, brokers and transporters, who also provided information on bush and primary markets beyond the borders of Kenya, where visits were impossible due to an unpredictable security situation. Data were also generated through structured and semi-structured interviews with government and NGO officials dealing with livestock production, trading, taxation and animal health. Data on weekly livestock volumes, sales and animal products were obtained from the Department of Livestock Production in Garissa County. Finally, public media, national archives and academic libraries were consulted as sources of secondary data.

\section{Results and discussion}

\section{Garissa livestock market and dynamics of the trade}

This section gives a comprehensive picture of the actors, and logistical challenges of the Somali-Kenyan livestock supply chain in order to be able to discuss ensuing policy implications in the following sections. First, we focus on Garissa livestock market, the key hub in the supply chain; second, we look into the sourcing of livestock upstream from Garissa; and third, we follow the livestock downstream from Garissa to the markets and abattoirs in Nairobi, a main destination of Somali livestock. Livestock flows in the Somalia-Kenya-Ethiopia triangle are complex and shifting, but at the time of the study, traders in Garissa maintained that Kenya is a preferred destination for Somali livestock because of weaker state controls compared to Ethiopia and easier access to cash at the borders. Little (2005) in the early 2000s noted that $75 \%$ of the cattle from Garissa market headed for the terminal markets in Nairobi, but this proportion had dropped to around $30-40 \%$ by 2018 (Ng'asike 2019). One of the reasons is that since 2010, wealthier Somali traders, through shareholding or leasehold, have acquired ranches near Kenya's coast where their livestock is being fattened before sale for domestic markets or export through Arab importers in Mombasa. This is a risk management strategy that they have developed to access markets in a more organized manner and avoid spending a lot of time at the terminal markets waiting for all animals to get sold.

Garissa is the capital of Garissa County in northeastern Kenya. Its livestock market has turned into a cosmopolitan trade hub for livestock from south-eastern Ethiopia, southern Somalia and north-eastern Kenya. ${ }^{2}$ Since the 1990s, Garissa has expanded as a destination for Somali immigrants and their investments in livestock trade in particular (Weitzberg 2015; Carrier 2016). Flows of Somali livestock began to increase as a by-product of (1) structural adjustments that opened Kenyan borders by the late 1980s (Little 2005; Gertz 2008), (2) the collapse of the central state in Somalia in 1991 and (3) the ongoing violent conflicts in southern Somalia. In search of safer routes and markets, and benefitting from the

${ }^{2}$ Interview, elderly livestock traders, Garissa livestock market, 21 January 2018 


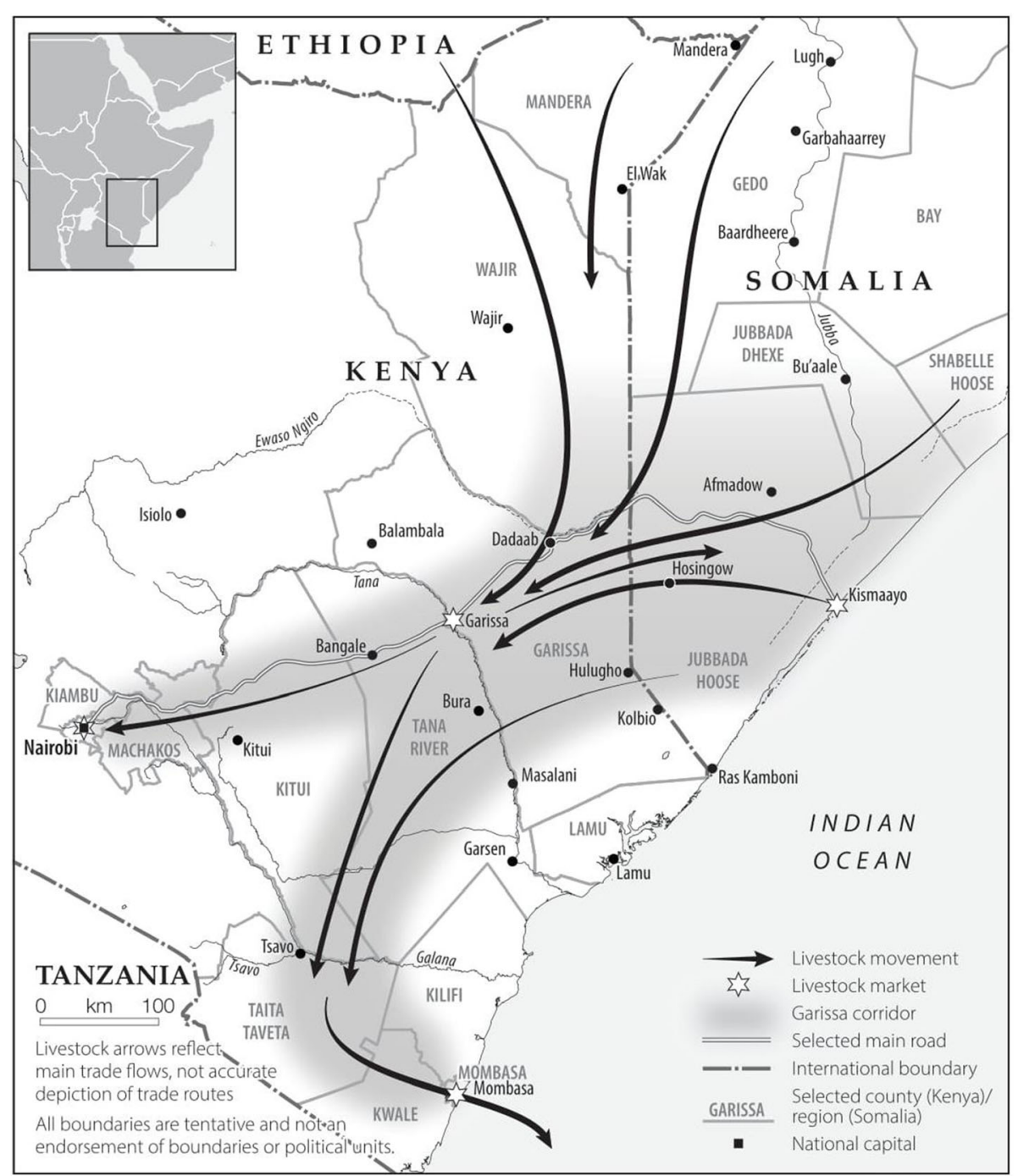

Fig. 1 Livestock trading and flows in the Somali-Kenya trade corridor, Source; Ng'asike et al. 2020

meat deficit in Kenya, Somali traders and brokers increasingly took their trade across the border to Garissa livestock market where they contributed to the growth of this market (see Fig. 2).

As a result, the location of the market in Garissa has shifted three times to avoid congestion from the growing volumes of livestock, trucks, trade operators, telecom companies, food stalls and other associated services. Tellingly, the most recent relocation (to Waberi in Garissa) was a result of negotiations between the local Somali Council of Elders and the local government in Garissa. The elders' council, which forms part of the Garissa's Livestock Marketing Association, makes decisions on market management, resolves conflicts and lobbies for infrastructural development.

Whereas small ruminants are traded daily, cattle are traded on Wednesdays only. Here, they constitute $90 \%$ of the animals traded; goats and sheep make up 7\%, donkeys $2 \%$ and camels, which are mainly traded at Bangale market in nearby Tana River County, less than $1 \%{ }^{3}$ An estimated $60-70 \%$ of the cattle comes from Somalia, ${ }^{4}$ typically the brown-reddish sahiwal. These are resistant to drought, large in size (grade II live weight ranges between 280 and $350 \mathrm{~kg}$ ) and fetching higher prices, as compared to the smaller Boran breed predominantly domesticated by pastoral communities in Kenya.

The cattle are mostly trekked into Garissa but leave the market for Nairobi in trucks. Operations start at $5.00 \mathrm{am}$, and by $7.00 \mathrm{am}$, the market is teeming with thousands of animals, trucks, motorbikes, brokers, petty

\footnotetext{
${ }^{3}$ Group discussion with livestock traders, Garissa market, 17 May 2018 ${ }^{4}$ Interview, Director of Livestock Production Office, Garissa County, 23 February 2019
} 


\section{Effect of state collapse and drought on cattle supply to Garissa livestock market}

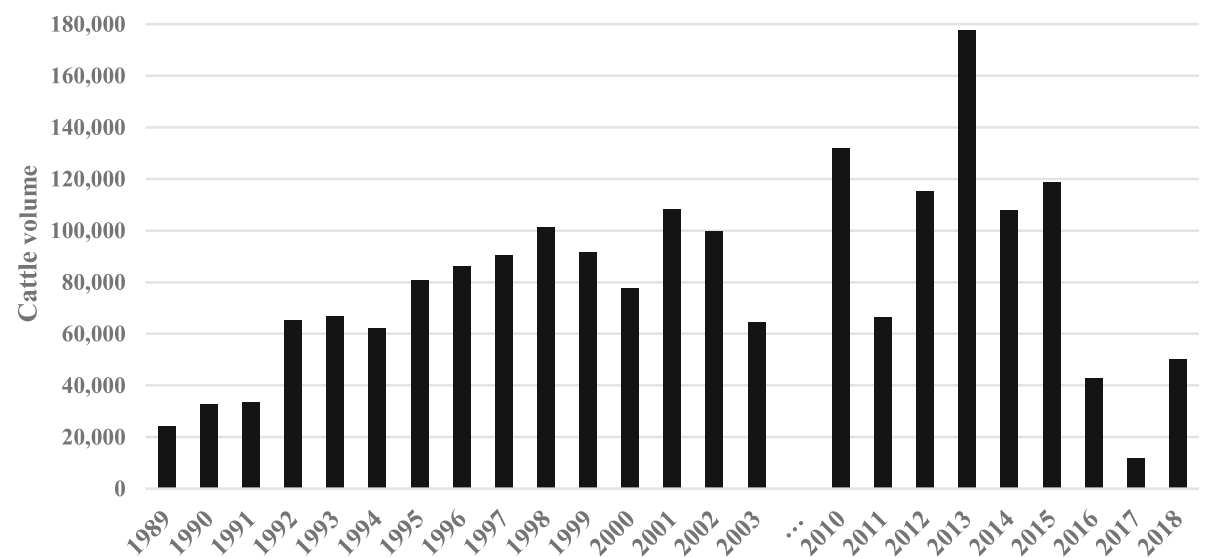

Fig. 2 Effect of Somalia state collapse (1991) and drought (e.g. 2016-17) on cattle volumes and sales at Garissa, 1989-2003. Data source: Little (2005) (1989-2003) and KLMC Garissa, 2018 (2010-18)

traders, vets, tax authorities, fodder sellers etc. The national government has been improving trunk roads and regional security, while international NGOs recently have invested in the market infrastructure and utilities such as water and hygiene. Since 2013, when devolution of resources and powers from the national level took place, the trade community had been expecting the local government to take on this role. Meanwhile, traders have been bearing the cost of sheds, pens/corralling and fodder to prepare animals for sale.

Traders and brokers who have brought livestock to Garissa have to register with the veterinary officials, who are always in the livestock market on market days. On other days they have to visit the Department of Agriculture, Livestock and Cooperatives to receive veterinary support and a movement permit that certify livestock for transportation. The movement permit declares the livestock free of disease and allows traders/brokers to bring the livestock into the rest of the country. In addition, the County's revenue office registers livestock for tax payment clearance. Brokers help the revenue officers evaluate the livestock size against market prices and gather the animals for counting. Traders who bypass clearance by the tax clerks in Garissa are charged the cess fees at the exit of Garissa County.

While congestion of the livestock market and the access roads is the normal state of affairs, this was not the case in 2016-2017, when consecutive droughts reduced the flow of cattle from 8 to 10,000 in the best of weeks the previous years to a trickle in 2016-2017. As a veterinary officer observed in early 2017, 'the market became dormant' because owners sought to escape the drought by taking their cattle to dry season pasture in Boni in southern Somalia or to the Kenyan coast. $^{5}$ As Fig. 2 shows, such annual variations are common and so are the seasonal variations which have been amply documented (see Huysentruyt et al. 2002; Le and Majid 2002; Doss et al. 2008; Hammond et al. 2011; Behnke and Muthami 2011). These variations influence prices as do seasons of high demand (festive seasons, religious celebrations) (Barrett et al. 2003).

\section{Sourcing and the stock routes}

Moving upstream from Garissa along the livestock supply chain, we find an intricate system of sourcing and an extensive network of stock routes reaching from southern Somalia and the Somali-Kenyan borderlands to Garissa. There is a high premium on distance as prices go down the deeper into Somalia the cattle are purchased. Traders who are willing to take the associated risks buy at an average of US $\$ 200$ per head in Somalia and sell at ca. US\$400 in Garissa and US\$500 in Nairobi. Small-scale traders and brokers who share clan affiliations with the producers buy small quantities of livestock from 'bush-markets'. These are villages or small market centres along shifting stock routes leading to places like Afmadow in Jubbaland in Somalia which have grown into primary markets where cattle are gathered in the hundreds. ${ }^{6}$ From there, trekkers are hired to bring the livestock to markets-mainly Garissa-across the border.

\footnotetext{
${ }^{5}$ Interview, veterinary officer, Garissa, 21 April 2017

${ }^{6}$ Interview with an elderly livestock trader, Garissa livestock market, 15 May 2018
} 
The security risks and poor road conditions mean that Kenyan trucks rarely venture into Somalia. Nevertheless, politically well-connected, larger Somali-Kenyan traders manage to have their agents buy and truck animals in Somali-driven trucks across the border. An estimated $20 \%{ }^{7}$ of the Somali livestock that enters Kenya do it this way; these traders' trucks stop to fuel outside Garissa while a boda-boda (hired motor-bike rider) picks up the necessary documents from the offices (without inspection) before continuing to Nairobi or the coast. The rest, however, is trekked across the border.

Numerous trekking routes link bush and primary markets to the main market hub in Garissa. Taking Boni in the south of Somalia as an example, three old stock routes lead from Boni westwards to Garissa: (i) BoniHulugho-Galmalagala-Degega-Bura-Garissa, (ii) BoniHulugho-Singailu-Ijara-Masalani-Bura-Garissa and (iii) Boni-Kulbiyo-Bulagolo-Dikhaharji-GalmagalaFafi-Garissa. A fourth route from Boni takes livestock southwards towards dry season pasture and water wells between Boni and Lamu on the Kenyan coast (BoniHulugho-Masalani-Budhai-Bargon-Hindi-MokoweLamu).

The trekkers are young Somali men, and they are specialists in choosing routes. Using mobile phones and scouting by motorbike, they manage local information on security situations, access to water and pasture and safe resting villages along the routes. Their main challenge is (informal) taxation and sometimes harassment by clan-militias, Harakat al-Shabaab al-Mujahideen (Al Shabaab) and Jubbaland authorities. Al Shabaab, for example, claims a tax of the equivalent of one head of cattle of a herd of 40-45, sometimes to be paid on the way back from Garissa. Trust and clan affiliations provide some security for the trekkers. Since they pass different clan territories on their way, trekkers manage security threats by cooperating and travelling with trekkers from the different clans to facilitate negotiation and protection for their caravans as they move across territories. ${ }^{8}$

Crossing the border, trekkers will often avoid the official custom points and use 'rat-routes'-less than an estimated $30 \%$ are formally taxed at the border ${ }^{9}$ - but there are good chances that they will meet military officials. The fact that the Ogaden clan forms the majority on both sides of the border facilitates the informal crossborder trade. However, for official checkpoints or

\footnotetext{
${ }^{7}$ Interview, Livestock Extension Officer, County Department of Livestock, 27 January 2018

${ }^{8}$ FGD, livestock trekkers, Garissa livestock market, 14 May 2018; see also Ononogbu and Nwangwu 2018

${ }^{9}$ Interview, Head of Kenya Livestock Marketing Council, Garissa, 19 February 2019. KLMC confirms that less than $30 \%$ of the cattle is formally taxed at the borderline. However, cattle that is trucked out of Garissa encounters formal taxation.
}

random encounters with the military, Swahili-speaking Somali trekkers with Kenyan IDs give an advantage in negotiations. According to the trekkers we have talked with, the military is mostly interested in local security intelligence, but after the attacks in Westgate, Nairobi (2014), and in Garissa (2015), harassment or arrest of Somalis (both Kenyan citizens and others) has been commonplace. ${ }^{10}$ Therefore, trekkers sometimes flee and leave the livestock behind when they see military patrols. Likewise, trucks in the borderland are routinely detained and have to pay informal fees for a swift release, which is factored into the trader's calculated costs. ${ }^{11}$

In sum, livestock traders, brokers and trekkers rely on clan connections for protection and management of the flows, and if conflicts occur at smaller source markets in the borderlands, elders' councils, sometimes in collaboration with the local police officer, will mediate and seek immediate solutions (Ng'asike 2019). For livestock operators, time is an important factor, and they prefer not to spend time on cumbersome formal procedures on the way.

\section{Terminal markets and abattoirs}

Whether going west to Nairobi or south towards the fattening ranches close to Mombasa, livestock trucks from Garissa and the borderlands must pass the narrow bridge over the long and crocodile-infested Tana River. With a roadblock manned around the clock by military and police, including bilingual police officers, the bridge effectively serves as a border. Clearance papers acquired from veterinary and revenue authorities in Garissa are necessary for legitimate passage, including an 'export tax' of US\$36 (Kshs. 3600) per truck, charged by Garissa County. There are no corresponding import tax or customs on the other side, though.

The road to Nairobi is infested with roadblocks, and livestock trucks risk being checked and detained for a variety of reasons and having to pay bribes to continue. Traders have included such payments-often more than US\$20 (Kshs. 2000) for the whole stretch, according to their accounts-in their business plans because of the importance of keeping transport time short. If the animals are weakened when they arrive at the terminal markets, additional expenses are required to restore their condition and secure a reasonable price. ${ }^{12}$ Therefore, traders even help each other by bailing out partners who find themselves in trouble with the kanjos (state officials); surprisingly, bails are often paid on credit through phone calls.

\footnotetext{
${ }^{10}$ FGD, trekkers, Garissa livestock market, 14 May 2018

${ }^{11}$ FGD, elderly livestock traders, Garissa market, 21 January 2018

${ }^{12}$ Extra expenses are US $\$ 1.50$ per day by 2019 , including payments for the herds boy, access to fodder and corralling at night.
} 
In Nairobi, the livestock arrives at the terminal markets, most of which have both a sale-yard and abattoirs. Here, livestock from Somalia/Garissa mix with livestock from other regions, such as the Rift Valley or the borderlands with Tanzania (Migori), Ethiopia (Moyale) and Uganda (Malaba). Officials verify the veterinary clearance and movement permit that indicates the date, the number of animals and the source market, before animals are offloaded into the sale-yards and traded once or twice before ending up in an abattoir. Approximately $70 \%$ of transactions are based on informal credits; not least traders from borderland hubs offer animals on credit to minimize the time and expenses spent in Nairobi. Clan mechanisms ensure that defaulters are traced and sanctioned. Default rates are low among Somalis, ${ }^{13}$ but trust is also built between traders of different groups.

Based on live weight, body condition and gender, prices are settled through negotiations between traders arriving with animals from the borders and brokers and butchers at the terminal markets. Grade II cattle costs between US $\$ 500$ and 550 (Kshs. 50,000-55,000), which is US\$100-150 (Kshs. 10,000-15,000) more than in Garissa. Prices vary depending on the volumes supplied. However, most butchers prefer buying beef on dead weight using scales, at an average cost of US\$3.0 (Kshs. 300) per $\mathrm{kg}$, at the abattoir, while they charge US $\$ 4.0$ (Kshs. 400) per kg when they sell the meat at the retail outlets.

Nairobi has several large and mainly private abattoirs. Some of these, such as Nema-Ruaka, KMC and Hurlinghun Ltd., have been certified for serving export markets. The rest, such as Dagoretti (for cattle), Kiamaiko (for small ruminants) and Mlolongo (for camels), cater for domestic markets. In the experience of traders, the prices they get for animals for the export markets are $20 \%$ higher than the prices for animals for domestic markets. Hence, they would like to sell more for export than they do currently but argue that they need help from the government to facilitate access to new markets.

Even though most of these abattoirs have gradually expanded in response to growing markets since 2000, they are still sometimes overwhelmed by the supply in peak seasons. Challenges also arise when producers sell their livestock in large numbers to avoid losses during a looming drought. Some abattoirs are competing for space with informal settlements that encroach on their premises, which causes environmental and hygiene problems. The National Environment Management Authority (NEMA) and the State Department of Environment are responsible for controlling the abattoirs' compliance with environmental laws and the sanitary and

\footnotetext{
${ }^{13}$ First author's estimate is less than $5 \%$.
}

phytosanitary (SPS) regulations. They can close abattoirs that do not meet the standards or comply with the laws. An example is the Kiamaiko abattoir (in Nairobi), which was closed for 2 weeks in April 2018. ${ }^{14}$ At the time of writing, there are municipal relocation plans due to its position within informal settlements.

The only internationally certified public abattoir in Nairobi is the Kenya Meat Commission (KMC), the biggest and most modern export abattoir, sending an average of 500 tons of chevon and mutton abroad every week. ${ }^{15}$ Formerly a state monopoly, the KMC has lost its position due to mismanagement and liberalization. According to traders, KMC was a reliable market destination before devolution, but since then, in particular, smaller traders have preferred other abattoirs because KMC takes months to pay the traders. But as we will see later in the "Policy, devolution and livestock trade in the Garissa corridor" section, KMC also has an important drought response function.

\section{Somali-Kenyan livestock trade on balance}

Over the years, trade operators in the Somali-Kenya trade corridor have managed to keep the livestock flowing with sufficient gains to overcome challenges of security and other risks. Small, often female, traders focus on Garissa itself and markets on the Kenyan side of the border, making limited profits and largely circumventing formalities. Mid-level traders cooperate to rent trucks or trekkers and shoulder various costs between Somalia and Garissa and between Garissa and Nairobi or destinations on the coast. From south Somalia to Garissa market, one head of cattle gains US $\$ 200$ in price, giving a profit of maybe US\$150, while the price-gain between Garissa and Nairobi is US\$100-150, giving the trader a profit of maybe US\$50-100. The big traders who truck cattle all the way from Somalia to Nairobi while bypassing Garissa market can make maybe US\$240-290 per head of cattle. These are very rough estimates that exclude losses on the way. ${ }^{16}$ They include conservative estimates of costs on the Somali side of the border, since trekkers/traders are hesitant to give information apart from the zakat charged by Al Shabaab (amounting to US $\$ 10$ per head). Conservatively, informal costs on both sides of the border could make up US $\$ 13$ of total costs of US\$75 per head of cattle (or US\$60 when bypassing Garissa market).

According to traders, access to veterinary services, certification and permits have improved after devolution,

\footnotetext{
${ }^{14}$ Maurine Kinyanjui, 'Kiamaiko goat market to close over hygiene, ownership issues,' 12 December 2018, The Star, Kenya

${ }^{15}$ Agatha Ngotho, 'Kenya may soon be able to export beef products to Europe', 23 January 2016, The Star.

${ }^{16}$ Estimates are based on 2018 figures given in Ng'asike (2019: 12) and in this article for cattle trucks with 25 heads.
} 
which has reduced such barriers to formalization. However, the increased number of encounters with officials has introduced other forms of informality, such as surcharges and inflated taxes, informal charges for passage of roadblocks, and extension of permits without actual veterinary inspection. While informality presumably benefits larger traders in urban centres while making small producers more vulnerable (Mahmoud 2003; Little 2005), we do not have data to show how the developments since devolution have influenced different levels of traders. Small traders are still vulnerable and avoiding formalization, while medium and wealthy traders endure high logistical costs, nevertheless, Kenya remains a preferred destination for Somali livestock, according to traders in Garissa.

\section{Policy, devolution and livestock trade in the Garissa corridor}

In this section, we explore some important policy implications and questions raised by the trans-national livestock supply chain that we have depicted above. We focus on the intersection of the county- and nationallevel governance as they have developed since devolution. This is also the main event making a difference between our study and Little's (2003) classical studies from around 2000. We focus on (i) ICBT, which is mainly a national government issue; (ii) the governance of market places which is a function of the county government; and (iii) issues of road infrastructure, abattoirs and droughts which involve both levels of government.

\section{Border policies and informal cross-border trade (ICBT)}

Livestock trade across the Somali-Kenyan border contributes to livelihoods and local government coffers in and beyond the borderlands, alleviates the meat deficit in Kenya's domestic markets and helps Kenya earn foreign currency through exports. Hence, from an economic point of view, Kenya has little incentive to hinder or criminalize the informal livestock imports, which in Garissa County constitutes an estimated $70 \%$ of imported livestock. ${ }^{17}$

Furthermore, given the practical challenges of controlling the vast and permeable border with extremely few roads and official border posts, it is not realistic, in the short run, to see the country launching a vigorous policy to control the highly flexible informal livestock import 'on the hoof'. This became clear after Kenya in 2014 officially closed her borders due to security concerns. Somali lobby groups protested and public media attributed increased insurgency activities to the plan to install

\footnotetext{
${ }^{17}$ Interview, Head of Kenya Livestock Marketing Council, Garissa, 22 January 2018.
}

formal barriers at Liboi and Mandera borders. ${ }^{18}$ The closure and increased surveillance created problems for livestock trade operators, but they have adapted to the situation through different tactics as described above, and so have well-connected operators of trucked contraband items, such as sugar (Rasmussen 2017).

During the 2010s, international agencies such as the African Development Bank (Afrika and Ajumbo 2012) have recommended states not to criminalize crossborder flows of agricultural products and livestock. Hardened bureaucratic border passages tend to increase corruption, to make transaction costs a problem for small-scale trade operators and to motivate evasion of formal procedures. According to the Bank, states should rather support these flows by combining services (such as credit schemes, security, fodder) with registration and licencing and simpler import/export procedures ('Simplified Trade Regimes') in order to progressively formalize the, often vital, cross-border trade.

In East Africa, IGAD followed suit in 2018 by communicating a policy framework in support of borderland communities that often depend on ICBT for their livelihoods. The framework recognizes these communities as 'frontiers of regional cooperation and integration' and proposes 'important policy shifts' in the management of ICBT as a way of improving 'cross-border security governance' and enhancing human security in the borderlands (IGAD 2018:2). Apart from the change in understanding of ICBT, and facilitating passage at border points (such as El-wak, Liboi, Dif and Kolbio, in the case of the Somali-Kenyan border), IGAD recommends states to increase (non-specified) investments in infrastructure and social services in the pastoral borderlands, which in the Kenyan and other cases have been heavily neglected since colonial times (Omiti and Irungu 2002; Murunga 2005).

From the perspective of our study and the observed dynamics in the Somali-Kenyan borderlands, we will make three observations:

First, since the 1980's restructuration programmes and the lowering of toll tariffs, Kenya has been quite permissive of ICBT in food products across the borders because of its assumed benefits for food security in borderland communities (Little 2005; Gertz 2008), and ICBT is very well developed (Little et al. 2015). As the description above suggests, it is the brokers/ small traders/trekkers and their trust- and clan-based business networks that engineer the flows of livestock into Kenya. These networks and the local knowledge embedded herein provide some measure of security,

\footnotetext{
${ }^{18}$ Stephen Astariko; Star times; Reopen Liboi border point for trade-MP; 01 February 2017. Posted at www.the-star.co.ke/counties/ north-eastern/2017-02-01-reopen-liboi-border-point-for-trade-mp/
} 
(informal) credit and access to fodder and water, albeit precariously. Therefore, if state-backed trade support facilities shall succeed in making it attractive for trade operators to formalize their business, this support has to be more effective than the resources and services already provided through informal, clanrelated networks.

Second, borders and borderlands are typically a domain of security and sovereignty-related concerns. The Somali-Kenya border is a clear example, with Al Shabaab's activities and Kenya's involvement in military operations in Somalia as immediate drivers of insecurity (Anderson and McKnight 2014). Thus, even though Kenyan security forces have little incentive to hinder cross-border trade as such (Lind et al. 2017), they tend to suspect Somali trade operators of being involved with Al Shabaab. The IGAD (2018) communique, mentioned above, encourages member states to enhance harmonization between ICBT policies and those of cross-border security governance, but it is signed by Ministers of Trade, who generally have less sway in governments than executives in security and foreign affairs departments.

Third, while there is evidence that a regional approach can help the introduction of reforms in the approach to ICBT (Prichard 2008), the fact that the Federal Government of Somalia (FGS) has very limited territorial control represents a problem for the development of borderland policies and the control/facilitation of livestock flows across the Somali-Kenyan border. If the FGS would benefit from livestock exports to Kenya, they might be interested in negotiating about ICBT, but they do not. As we saw, trade operators pay their zakat, fees and informal taxes to Al Shabaab, militias, Jubbaland and local authorities to access water points, stock routes and protection in Somali territory.

Governments in the Horn of Africa in general have been slow in committing to common arrangements for monitoring and control of diseases across borders, which seems to be the Achilles' heel of ICBT in livestock (Sandford and Ashley 2008; IGAD 2016). However, the Somali authorities are in a particularly poor position: they cannot realistically issue the health certificates necessary for formal import into Kenya nor can they commit themselves to engage in cross-border disease management arrangements.

In terms of import control in the borderland, there is more focus on security than on the flow of commodities; both levels of government are concerned with improving livelihoods rather than enforcing taxation. Hence, the de facto border in the Garissa corridor is located $150 \mathrm{~km}$ into Kenyan territory at the bridge over Tana River where the road exits Garissa towards central and coastal Kenya. Here, compliance and county revenue officials check the permits that traders acquire in Garissa. After this, the livestock is allowed to enter the rest of Kenya where it is traded as a formal Kenyan commodity, rather than a product of ICBT. Being inside Kenya, traders pay taxes to the local authorities and may receive Kenyan export permits.

As mentioned above, Kenyan-Somali traders would like to access international markets because of the higher prices, but with the current situation in the borderlands, Kenyan exports are vulnerable vis-à-vis international SPS and commodity standards, including the increased demands for traceability in production and breeding systems of free-range grazing animals. ${ }^{19}$ According to people interviewed, veterinary services have been pushed to the borders since devolution in $2013 .{ }^{20}$ With the capacity-building of community animal-health workers, the surveillance and reporting of diseases have improved, and herders have learned how to identify common diseases caused by changes in weather. Even producers on the Somalia side of the border are benefiting as pharmaceuticals are sold at the borders. As our observations and interviews in Garissa have shown, procedures are not always bullet proof; in practical terms, disease control depends on the traders/brokers and the officials of the Livestock Marketing Associations.

\section{Devolution and market governance}

Livestock trade is the most important local source of revenue for counties in Kenya's semi-arid borderlands in the north and east of the country. With devolution, the central government empowered county governments to manage and take responsibility for livestock markets, but in practical terms, national and international actors continue to dominate policy-making in the sector. ${ }^{21}$ Counties are supposed to develop 'sale-yard bills'. These should include co-management arrangements with formal 'Livestock Marketing Associations' (LMAs), but the process is slow, and county governments have primarily seen livestock trade as an easy way to increase revenue, without improving market services or infrastructure in return. Thus, a recent analysis describes livestock markets in northern Kenya as not functioning properly and as being poorly governed in terms of the implementation of rules and regulations, as well as accountability for the revenue collected (Njiru et al. 2017).

\footnotetext{
${ }^{19}$ The Kenyan government is currently planning a 'livestock identification strategy', according to the Director of the state Department of Livestock at the ADIS workshop in Nairobi, 30 October 2019.

${ }^{20}$ Focus discussion, livestock traders, Garissa market, 21 January 2018

${ }^{21}$ This was one of the conclusions from the ADIS workshop on livestock trade and devolution, Nairobi, 30 October 2019.
} 
Garissa livestock market, as one of the largest of its kind in this part of Africa, is better organized and equipped than many other markets in northern Kenya. But as our study shows, facilities and services are still insufficient in terms of water, sanitation and hygiene, fodder, security, access roads, feeding troughs, animal sheds and pens, food stalls, formal banks and loading ramps. ${ }^{22}$ The county government is authorized to charge a market tax which in 2018 was supposed to be Kshs. 100 for big stock (cattle, camels) and Kshs. 20 for small ruminants (goats and sheep). These taxes have increased since devolution, both at primary and secondary markets, ${ }^{23}$ but in addition, traders at Garissa inform that they pay Kshs. 310 for big stock (including Kshs. 100 for the sheds or pens) and Kshs. 100 for small stock, which is 3-5 times the standard fee. In the busiest weeks of the high season, the county government's revenue from cattle taxation alone reaches over US\$10,000 (Kshs. 1 million), ${ }^{24}$ in addition to the tax revenue from camels, goats and sheep. In 2018, which was a below-average year, the local authorities extracted just above US $\$ 3$ million (Kshs. 0.3 billion) in revenue from the livestock traded. In the 2019 budget, 'cattle auction fees' contribute only US $\$ 0.2$ million, of which an estimated $60-70 \%$ comes from Somali cattle. ${ }^{25}$ In total, the revenues that Garissa County collects made up only $7 \%$ of its annual budget in FY 2016-2017, and even less (2-3\%) in the 2019 budget; the rest of the budget is made up by transfers from the national government and grants. ${ }^{26}$

With devolution, the County assumed responsibility for veterinary control and the issuing of the 'movement permit' that allows traders to move and sell the livestock across the country. The official charge for this permit was Kshs. 75 in 2018, but traders in Garissa livestock market pay over Kshs. 2000, according to one official. ${ }^{27}$ This practice suggests that traders are poorly informed, and their organizations are unable to negotiate and pressure for a change. Presently, traders, brokers and producers are handicapped because their access to markets depends on documents issued by the veterinary and revenue departments.

\footnotetext{
${ }^{22}$ Interview, trader, Garissa livestock market, 11 May 2018

${ }^{23}$ Interview, Head of Kenya Livestock Marketing Council, Garissa, 22 January 2018.

${ }^{24}$ Cattle volume of 5000 heads, taxed at the rate of US\$2.10 (Kshs. 210) per head

${ }^{25}$ Interview, Director of Livestock Production Office, Garissa County, 23 February 2019

${ }^{26}$ Kenya Markets Trust 2016, p. 24 (for FY 2016-2017), and Garissa County Budget Estimate, April 2019, posted at http://www. youthagenda.org/mainwebsite/wp-content/uploads/2019/12/GarissaCounty-Budget-Estimate-2019.pdf. (accessed 8 April 2020)

${ }^{27}$ Informal discussion with the state officer, department of livestock, Garissa County, June 2018
}

Turning to the organization and governance of the market, we have noted in our account above that formal and informal forms of governance overlap. This is also clear when we look at Garissa's LMA. Since the 1990s, a Somali Council of Elders has represented traders and others vis-à-vis the local government, and in 1998, it was formalized as a LMA. The council/association has primarily undertaken the important function of solving conflicts in the marketplace. The members are mostly traders and Elders, representing various sub-clans, but neither female nor non-Somali traders are members of the association. ${ }^{28}$

According to county Sale Yard Bills - which is still pending in Garissa and other counties - LMAs are mandated to co-manage the market and are expected to engage in service fee collection (loading fees), coordination, identification of needs for improvement and repair, dissemination market information, and to take on responsibilities in the registration and control of animal diseases (Njiru et al. 2017). Both in terms of such responsibilities and of officials and members, there are considerable overlaps with the County Livestock Marketing Council (CLMC), an umbrella for all markets in Garissa County that has existed since devolution, and the local branch of Kenya Livestock Marketing Council (KLMC). While these three structures have been supported through capacity-building and other means by donors and NGOs, they seem to become somewhat dormant when they are not actively funded.

However, in 2016, Garissa's LMA spearheaded a protest against the county's increased taxation because the local government had not done anything to improve services in exchange for the taxes. ${ }^{29}$ And in 2017, the local government granted the LMA $5 \%$ of the revenue collected in the market in addition to the proceeds from the charges (US\$6 (Kshs. 600) for a short truck and US\$12 (Kshs. 1200) for a long truck) from one of the two livestock loading ramps in the market. ${ }^{30}$ If LMAs are to have a chance to 'co-manage' livestock markets and undertake important responsibilities, this kind of arrangements seems to be indispensable.

Equally important is the involvement of the LMA and other market actors in plans for upgrading the livestock market. Recently, the World Bank and USAid funded the improvement of the market infrastructure by constructing market stalls, but the petty traders opposed the project because they suspected that it would just be

\footnotetext{
${ }^{28}$ Masai traders from the Rift Valley are increasingly present in the market where they look for Somali Sahiwal cattle for breeding. Interview, Head of KLMC, Garissa, 19 January 2018

${ }^{29}$ Informal discussion, Head of Kenya Livestock Marketing Council, Garissa town, 19 January 2018

${ }^{30}$ Interview, Head of Kenya Livestock Marketing Council, Garissa, 19 February 2019
} 
another trick by the government to extend taxation to small-scale business operations such as tea selling. This illustrates the lack of trust in authorities after many years of negative experiences, and it shows the need for analysis of use patterns in order to make plans that fit the purpose and take the actual rather than idealized uses into account. The lack of participatory appraisal and neglect of community opinions are the main gaps that caused market actors and the rest of the community to be suspicious over government/NGO developmental plans.

With devolution, the county has been given the responsibility for other market-related functions, such as the licencing of livestock traders, so now trade permits are extended in Garissa rather than in Nairobi. Another responsibility is the county abattoir. Like other counties in northern Kenya, Garissa invested about US\$50,000 (Kshs. 5 million) in the construction of an abattoir in 2016 to boost the livestock industry. However, as in several other counties, Garissa's abattoir is still incomplete, making the project look like a 'white elephant. ${ }^{31}$ Furthermore, hygiene and SPS standards are not always respected in the old and small abattoir, which is always congested and over-stretched. Veterinary doctors tend to bend health and sanitary regulations to allow the abattoir to continue operations and continue supporting the livelihoods that depend on this facility. ${ }^{32}$

\section{Other governance issues}

Apart from ICBT and the governance of livestock markets, several other issues of governance-issues that linger between county and national levels of administrationhave an impact on livestock trade. Some of the most important issues are roads, abattoirs and drought responses.

Road infrastructure plays a key role in the Kenyan livestock trade, where transport costs make up an estimated $45 \%$ of the total distribution costs for cattle and $32 \%$ for small ruminants (Njiru et al. 2017). Time spent on the road is expensive and detrimental to the livestock, and poor road conditions increase the risks for the animals and expenses for truck repairs. ${ }^{33}$ In Garissa County (of $44,000 \mathrm{~km}^{2}$ ), only $30 \mathrm{~km}$ of a total of $1800 \mathrm{~km}$ of road is tarmacked, and many of the roads used to supply Garissa market are not passable all-year round. Improvement of major roads that link Garissa to Mombasa or Nairobi is the responsibility of the national government, however - the road to Mombasa is in a very poor condition, and truck owners prefer the Nairobi route to avoid

\footnotetext{
${ }^{31}$ ADIS workshop on livestock trade and devolution, Nairobi, 27 October 2019

${ }^{32}$ Informal discussion with the state officer, department of livestock, Garissa County, June 2018

${ }^{33}$ Informal discussion with livestock transporters, Garissa livestock market, 24 April 2017
}

the costs of truck repairs. As part of the Lamu Port, South Sudan, Ethiopia Transport Corridor project (LAPSSET), the national government has embarked on building a highway which will connect Lamu (on the Coast) with Garissa and continue onwards to Isiolo, from where it joins the new Isiolo-Marsabit road to Moyale town at the border with Ethiopia. The construction of a branch towards the eastern border town of Mandera was commissioned in 2016. Traders in Garissa have very high hopes for the benefits that these roads are expected to bring their business. ${ }^{34}$

Like roads, the governance of abattoirs is split between local and national governments. Since devolution, county administrations have been responsible for controlling whether county abattoirs comply with the national sanitary and phytosanitary standards (SPS). This regulation cuts across private and public slaughterhouses to guarantee the safety of meat consumers, and it is enforced as a national-level issue under the 'National Environment Management Authority'. Since most of the private abattoirs are too strained to invest in hygiene and meet official demands, compliance agencies are regularly threatening to close abattoirs. ${ }^{35}$ The encroachment of informal settlements on the premises of the abattoirs, for example, is causing problems of hygiene, congestion and environment, as in the case of Kiamaiko abattoir in Nairobi. ${ }^{36}$

Unlike in northern Kenya where counties have invested in public, but sometimes unfinished and often un-sustainable abattoirs, in central Kenya abattoirs are mainly private. Therefore, counties have little incentive to develop abattoirs' infrastructure. Hence, the abattoir managers interviewed for this study have not been impressed by what they get in return for the taxes they pay. They have also expressed frustration with the lack of initiative from the central government in terms of opening new meat export markets.

At a more general level, the limited number of internationally certified abattoirs reduces the capacity for meat export. ${ }^{37}$ Small and medium traders are interested in accessing export markets, but it is not clear why the national government has been slow to facilitate openings for them. Bilateral engagements are underway to facilitate market access and reduce strict regulations along the borders, as driven by the security agenda on the

\footnotetext{
${ }^{34}$ Discussion with livestock traders, Garissa livestock market, 15 May 2018

${ }^{35}$ Interview with the manager of Nyongara unit, at Dagoretti abattoir, 21 July 2018

${ }^{36}$ Ibid., and informal discussions with butchers at Kiamaiko slaughterhouse, August 2019

${ }^{37}$ Interview, butcher at Dagoretti abattoir, on 16 July 2018, then supported by the discussion with the Director of the state department of livestock, National Government, during the Livestock Stakeholders Research Feedback workshop, at Garissa, on 11 June 2019.
} 
Kenyan side and undermined by the lack of effective controls on the Somali side. In west Africa and South Africa, these bilateral engagements have established disease-free zones and channels of livestock certification, which for example has given livestock production in Botswana global recognition (Bernard and Darkoh 2014).

Finally, the response to recurring droughts in livestock-producing areas is another important area of governance with implications for livestock trade. Drought has highly differentiated effects on traders. Wealthier ones have the resources to benefit from the low prices when poorer traders and producers have to sell their emaciated animals. As mentioned, drought was also a driver for the acquisition of fattening ranches near the Kenyan coast. Disaster response is on the list of both national and county governments' functions and powers, ${ }^{38}$ but in terms of drought and disease monitoring, the institutionalized response is located at the national level in the shape of the state-managed Kenya Meat Commission (KMC), the export-oriented abattoir mentioned earlier. It was established in 1950 to protect drought-affected producers by cushioning them against losses through destocking programmes. ${ }^{39}$ As it worked during the droughts of 2016-2017, KMC paid US\$50 (Kshs. 5000) per head of cattle disposed for slaughter. ${ }^{40}$ As a buyer of last resort, KMC protects producers against plummeting prices, but traders in Garissa found KMC's price highly exploitative. ${ }^{41}$ Garissa County distributed fodder and pasture to pastoral villages, but the number of beneficiaries was limited, and assistance did not reach many villages in the insecure borderland. Producers tried to move their herds to more droughtresistant areas, such as the coast between Kismayo and Lamu, but such migrations expose them to risks, including the risk of stirring up conflicts over land and resources. ${ }^{42}$

\section{Conclusion and recommendations}

Livestock trade forms an essential part of the supply chain for meat and other animal products. In Kenya, operators of the trade move livestock across international as well as county borders, bringing livestock from the

\footnotetext{
${ }^{38}$ See the 'Fourth Schedule' of the Constitution on the distribution of functions and powers between national and county governments.

${ }^{39}$ Livestock Stakeholders Research Feedback workshop, at Garissa, on 11 June 2019

${ }^{40}$ Interview with senior livestock trader and broker, Garissa, 21 March 2018

${ }^{41}$ Discussion with traders, Garissa livestock market, 23 January 2018

${ }^{42}$ Interview with the Director of Livestock Production, Garissa County government, 23 February 2018. In general, governments are not good at addressing the common impacts of drought and supporting the strategies of producers and traders (Scoones and Graham 1994; Little et al. 2001)
}

vast pastoral areas of production to the congested centres of consumption and redistribution. The management and regulation of trade are complicated by crossing administrative boundaries and different territories of policy and regulation. This has been accentuated by the devolution in Kenya, where an ambitious programme of decentralization of functions and powers was inscribed in the new 2010 Constitution.

However, management and regulation are also complicated because trade operators move livestock in and out of formal and informal regulatory frameworks on the way to terminal markets. In the case of the flows of livestock from the Somali-Kenyan borderlands, these frameworks are typically (1) state-centred legal and administrative ones that focus on taxation, licencing, standards, hygiene, environment and some provision of road and market infrastructures or (2) frameworks based on clan-related practices of trust-based and socially sanctioned forms of exchange. The latter are to a large degree responsible, in practice, for the conveyance of livestock through trust-based networks that provide contacts, conflict mediation and access to (some) security, water, pasture, information and (informal) credits.

The frameworks overlap and interact as when elders and police together mediate conflicts in small markets, when brokers facilitate the work of tax officials in the sale-yard or when the (Somali) Council of Elders in Garissa livestock market doubles as a Livestock Marketing Association. Furthermore, one thing is the framework, and another is the practices around them. Thus, formal institutions are shot through by unauthorized practices as when state officials overcharge for services and licences, when police agents use roadblocks to supplement their meagre wages or when veterinary officials turn their blind eye to un-hygienic practices in abattoirs or fail to control for diseases for various reasons.

With this background, we have investigated the implications that devolution has had for the partly international cross-border livestock trade in Kenya. It is clear that devolution has increased the reach of public services and made these more accessible in traditionally marginalized counties like Garissa, as in the case of veterinary assistance, registration and certification of livestock and licencing of traders. ${ }^{43}$ In addition, trade operators now consider the county an ally in lobbying against increased harassment and extortion by security forces in the borderlands.

\footnotetext{
${ }^{43}$ Some of these functions were present in Garissa before devolution, but officers were often absent as they came from Nairobi, according to traders.

${ }^{44}$ Presentations from the ADIS Workshop, 29 October 2019, at Westlands, Nairobi
} 
At the same time, however, devolution has produced various unintended consequences when seen through the lens of livestock trade: The definition and hardening of county boundaries has increased conflicts over land and pastures (including a strong dimension of ethnic/ clan-based strife), has blocked trade routes ${ }^{44}$ and has increased the burden of taxation because of increased rates and double taxation, both of livestock and abattoirs. ${ }^{45}$ Confronted with the need to increase county revenues, they have opted for taxation of trade flows as an administratively very simple form of taxation.

Furthermore, due to the limited economic and human resources, counties are lagging behind in terms of developing their regulation of trade and market places, developing information systems to reach producers and make them less vulnerable to brokers who are at an advantage by having access to market information, and helping the Livestock Marketing Associations (LMAs) in developing their monitoring, registration and statistics. It also seems that the counties' veterinary service, despite improvements, has some way to go in terms of scope, capacity and quality.

Finally, it seems that the devolution of power and functions to the counties has reinforced oligopolistic power around leading political figures in county politics, thus concentrating resources among families and friends of the executives. In livestock trade, this means for example a concentration of trucks and increased control over the supply chain. Also, the lack of feasibility studies, transparency and consultation in the construction of county abattoirs speaks to such unfortunate implications of devolution. ${ }^{46}$

Looking to the future of livestock trade in Kenya, it will be important to manage issues at the intersections of county and national governments and administrations. We will mention four of these, based on our analysis of the Somali-Kenya corridor.

First, considering the situation in Somalia, it will take some time before Kenya can make effective, bilateral agreements over cross-border trade with the Federal Government of Somalia (FGS). The main problem herein lies in the lack of cross-border disease control and the risk of international trade bans. For all practical purposes, the screening for diseases of 'imported' livestock destined for national and export markets has become the responsibility of Garissa County's directory of veterinary services. Considering their limited capacity and the idea of the co-management of markets, the directory relies on its cooperation with 'community/lay veterinarians' in the extensive county and the various

\footnotetext{
${ }^{45}$ Dagoretti abattoir in Nairobi is a case in point.

${ }^{46}$ As expressed by observers from various counties at the ADIS workshop, Nairobi, 27 October 2019
}

Livestock Marketing Associations to help in identifying and controlling diseases. While living up to international standards of disease-free areas might be unrealistic (as argued by Prichard 2008 and others), it may be necessary to set up or strengthen a system of quarantine to satisfy Kenya's existing and potential export markets. As the national government is responsible for international trade, it should coordinate with counties on how to implement such a system.

Second, as road transport makes up a substantial part of the time and money spent on distribution, the improvement of roads should bring down costs considerably, as would a reduction of police roadblocks and the unauthorized charges. The national government and donors are in the process of improving highways in northern border counties, but it appears unrealistic for the time being to expect counties to make similar investments in feeder and secondary roads.

Third, since disaster management is primarily a national responsibility, county governments should join and take the lead in developing drought responses, also beyond the existing destocking programme of the Kenya Meat Commission. This could take the form of emergency funds to cushion producers against stress and losses during extended droughts, and ideally, counties in northern Kenya should develop abattoirs, to help the Kenya Meat Commission to expand its operations during the drought seasons, through destocking programmes.

Finally, it is an open question if the national government can do something to counter what seems to be a general problem of increased oligopolistic power concentrated around county executives, including in the livestock supply chains. This puts small and medium traders at a disadvantage and delimits the spread of livestock trade benefits to more people. A key strategy is to improve livelihoods and resilience by channelling resources to small and medium enterprises (SMEs) and continue the kind of NGO, World Bank and governmental programmes that support formal and informal associations and groups of youth and women in urban centres.

These issues point towards the need of coordinating developments in the regulation of livestock trade between national and local-level administrations, and indeed between counties. Therefore, we see an important role for organizations like the Frontier Counties Development Council and the Kenya Livestock Marketing Council. Considering the prospects for increasing meat exports, and improving the general protection of Kenyan consumers, one of the pertinent questions for these organizations is how to make the local administration's veterinary and SPS control more efficient while 
recognizing that the flexibility, drive and resources of an extensive 'informal' organization, underpinned by clan relations and norms, is what makes the cross-border livestock trade possible.

Compared to the 2000s, much has changed in Garissa, and it is a clear impression from the interviews undertaken for this study that Somalis no longer view themselves as asylum seekers in Kenya. Like Somali traders in Eastleigh, Nairobi (Carrier 2016), Garissa-based trade operators are making their contribution to the Kenyan economy, and they are ready to formally negotiate with the central government for the improvement of infrastructures and formal services to smoothen supply chains of livestock and other commodities, and ultimately expand their capacity and space in the Kenyan economy.

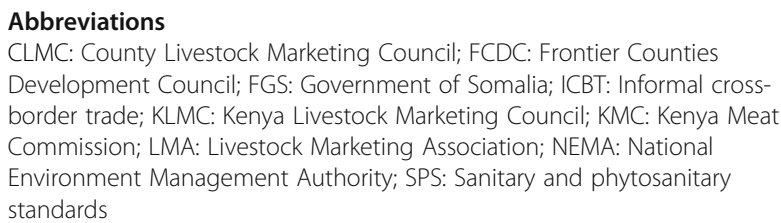

\section{Acknowledgements}

All authors confirm and acknowledge that the content of the manuscript has never been published elsewhere.

\section{Authors' contributions}

The corresponding author (PON) contributed by identifying the research problem; choosing the study method, data collection, data analysis and interpretation; drafting the manuscript; and submitting to the journal in consultation with the co-authors. FS and JNT contributed to the drafting of the manuscript, building the argument, providing intellectual support and revising different drafts of this article. All authors approved the final manuscript.

\section{Funding}

The paper is the work of a doctoral research work done by PON-the corresponding author; hence, there is no funding available for this publication.

\section{Availability of data and materials}

All the data used in the article result from fieldwork conducted by the first author along the Garissa-Nairobi trade corridor. Most of the data is included in the text and the source well acknowledged.

\section{Ethics approval and consent to participate}

All authors have approved the manuscript for submission.

The first author sought the consent of the respondents before conducting interviews and discussions.

The corresponding author also asked for permits to undertake research from University as well as the research institutions.

\section{Consent for publication}

Although the first and second authors have been working on the revision of the manuscript, the third author has read and consented to the resubmission of the revised manuscript.

\section{Competing interests}

The authors declared that they do not have competing interests.

\section{Author details}

'Department of Land Resource Management and Agricultural Technology, University of Nairobi, Nairobi, Kenya. ${ }^{2}$ DIIS, Danish Institute for International Studies, Copenhagen, Denmark.

Received: 7 July 2020 Accepted: 3 November 2020

Published online: 21 December 2020

\section{References}

Afrika, J.G., and G. Ajumbo. 2012. Informal cross border trade in Africa: Implications and policy recommendations. Africa Economic Brief 3 (10): 1-13.

Ahmed, Ismail I., and Reginald Herbold Green. 1999. The heritage of war and state collapse in Somalia and Somaliland: Local-level effects, external interventions and reconstruction. Third World Quarterly 20 (1): 113-127.

Anderson, David M., and Jacod McKnight. 2014. Kenya at war: Al-Shabaab and its enemies in Eastern Africa. African Affairs 114 (454): 1-27 https://doi.org/10. 1093/afraf/adu082.

Barrett, Christopher B., Francis Chabari, Deevon Bailey, Peter D. Little, and D. Layne Coppock. 2003. Livestock pricing in the northern Kenyan rangelands. Journal of African Economies 12 (2): 127-155.

Behnke, R.H., and D. Muthami. 2011. The contribution of livestock to the Kenyan economy. IGAD Livestock Policy Initiative. Working Paper No. 03 -11.

Bernard, Michael, and Kwesi Darkoh. 2014. Globalization and the livestock industry in Botswana. Singapore Journal of Tropical Geography 23 ((2) May): 149-166.

Carrier, Neil. 2016. Little Mogadishu; Eastleigh, Nairobi's Global Somali Hub. London: Hurst \& Co.

Doss, C., J. McPeak, and C.B. Barrett. 2008. Interpersonal, intertemporal and spatial variation in risk perceptions: Evidence from East Africa. World Development 36 (8): 1453-1468

Farmer, Elisabeth, and James Mbwika. 2012. End market analysis of Kenyan livestock and meat: a desk study." USAID micro-report 184. ACDINOCA. Accelerated Microenterprise Advancement Project. Nairobi.

Gertz, Geoffrey. 2008. Kenya's trade liberalization of the 1980s and 1990s: Policies, impacts, and implications. Background paper on the impact of Doha Round on Kenya. In Carnegie endowment for international peace's trade, equity, and development program. Nairobi.

Hammond, Laura, Team Leader, Mustafa Awad, Ali Ibrahim Dagane, Peter Hansen, and Cindy Horst. 2011. Cash and compassion: The role of Somali diaspora in relief, development and peace-building. Nairobi: UNDP.

Huysentruyt, Marieke, Christopher B. Barrett, and John G. McPeak. 2004. Social identity and manipulative interhousehold transfers among East African pastoralists." Cornell University Dept. of Applied Economics \& Management Working Paper.

IGAD. 2016. IGAD regional strategy: Volume 1: The framework. Vol. 1. Djibouti.

IGAD, and Communiqué. 2018. Meeting of ministers in-charge of trade from IGAD member states on a draft regional policy framework on informal cross-border trade (ICBT) and cross-border security governance (CBSG). Mombasa.

Le, Sage Andre, and Nisar Majid. 2002. The livelihoods gap: Responding to the economic dynamics of vulnerability in Somalia. Disasters 26 (1): 10-27.

Lind, Jeremy, Patrick Mutahi, and Marjoke Oosterom. 2017. Killing a mosquito with a hammer: Al-Shabaab violence and state security responses in Kenya. Peacebuilding 5 (2): 118-135 https://doi.org/10.1080/21647259.2016.1277010.

Little, Peter D. 2003. Somalia: Economy without state. Oxford; Bloomington: James Currey; Indiana University Press.

Little, Peter D. 2005. "Unofficial trade when states are weak: The case of crossborder commerce in the Horn of Africa." Research Paper No. 2005/13. Helsinki: EGDI and UNU-WIDER.

Little, Peter D., Hussein Mahmoud, and D. Layne Coppock. 2001. When deserts flood: Risk management and climatic processes among East African pastoralists. Climate Research 19 (2): 149-159.

Little, Peter D., Waktole Tiki, and Dejene Negassa Debsu. 2015. Formal or informal, legal or illegal: The ambiguous nature of cross-border livestock trade in the Horn of Africa. Journal of Borderlands Studies 30 (3): 405-421.

Luling, Virginia. 1997. Come back Somalia? Questioning a collapsed state. Third World Quarterly 18 (1): 287-302.

Mahmoud, Hussein Abdullahi. 2003. The dynamics of cattle trading in northern Kenya and southern Ethiopia: The role of trust and social relations in market networks. PhD Dissertation. Department of Anthropology, College of Arts and Sciences, University of Kentucky. 
Mahmoud, Hussein Abdullahi. 2008. Risky trade, resilient traders: Trust and livestock marketing in northern Kenya. Africa 78 (4): 561-581.

Mahmoud, Hussein Abdullahi. 2010. "Livestock trade in the Kenyan, Somali and Ethiopian borderlands." Africa Programme. Vol. 02. London: Chatham House. AFP BP.

Murunga, Godwin Rapando. 2005. Conflict in Somalia and crime in Kenya: Understanding the trans-territoriality of crime. African and Asian Studies 4 (1-2): 137-218

Ng'asike, Philemon O. 2019. "Fusing formal and informal trading: Emerging practices in the livestock value chains between Kenya and Somalia." DIIS Working Paper. Vol. 12. Copenhagen: Danish Institute for International Studies.

Ng'asike, Ong'ao P., Tobias Hagmann, and Oliver V. Wasonga. 2020. Brokerage in the borderlands: the political economy of livestock intermediaries in northern Kenya." Journal of Eastern African Studies (2020): 1-21.

Njiru, Nelly, Nadhem Mtimet, Francis Wanyoike, Adan Kutu, Abdikadir Songolo, Issak Dahir, and Galgalo Jillo. 2017. Assessment of livestock marketing associations in arid and semi-arid lands in northern Kenya. International Livestock Research Institute (ILRI) and USAID - Feed the Future Programme.

Ononogbu, O.A., and C. Nwangwu. 2018. Counter-insurgency operations of the African Union and mitigation of humanitarian crisis in Somalia. Mediterranean Journal of Social Sciences 9 (2): 117-117.

Prichard, Wilson, and David K. Leonard. 2008. The role of IGAD in shaping livestock policy in the Horn of Africa: Understanding the international system, international actors and implications for reform. IGAD Livestock Policy Initiative (LPI). Working Paper No. 12 - 08. Institute of Development Studies. Sussex.

Rasmussen, Jacob. 2017. Sweet secrets: Sugar smuggling and state formation in the Kenya-Somalia borderlands. DIIS Working Paper 2017. Vol. 11. Copenhagen: Danish Institute for International Studies.

Sandford, L., and S. Ashley. 2008. "Livestock livelihoods and institutions in the IGAD region." IGAD Livestock Policy Initiative Working Paper No., no. 10, 10-08.

Scoones, lan, and Olivia Graham. 1994. New directions for pastoral development in Africa. Development in Practice 4 (3): 188-198.

Too, Robert, Rachael Masake, George Oyoko, and Diana Onyango. 2015. The contribution of livestock to the Somalia economy. In IGAD Centre for Pastoral Areas and Livestock Development (ICPALD). Nairobi: VEDAMAN Consultants Limited.

Weitzberg, Keren. 2015. The uncountable census: Colonial enumeration and its implication for the Somali people of Kenya. Journal of African History 56 (3): 409-428.

\section{Publisher's Note}

Springer Nature remains neutral with regard to jurisdictional claims in published maps and institutional affiliations.

\section{Submit your manuscript to a SpringerOpen ${ }^{\circ}$ journal and benefit from:}

- Convenient online submission

- Rigorous peer review

- Open access: articles freely available online

- High visibility within the field

- Retaining the copyright to your article

Submit your next manuscript at $\boldsymbol{\nabla}$ springeropen.com 